\title{
ゼオライト高含有硬化体に及ぼす灰の品質の影響十
}

\author{
杉山 友明* 井野場 誠治*** 大塚 拓** \\ 日恵井 佳子**** 山本 武志**
}

\section{The Influence of Fly Ash Properties on Zeolite Composed Hardened Material}

by

\author{
Tomoaki Sugiyama*, Seiji Inoba***, Taku Otsuka **, \\ Yoshiko HieI $* * * *$ and Takeshi Yамамото $* *$
}

The discharge amount of coal ash was around 10 million tons every year from pulverized coal-fired steam plants in japan. Alkali activated aluminosilicate material, i.e. fly ash, attracts attention as a new usage for building material. Authors produced zeolite composed hardened material by mixing fly ash with sodium hydroxide solution and curing under hydrothermal condition at $180^{\circ} \mathrm{C}$. This material has high strength and cation exchange ability against cesium. This paper discusses the influence of variation in physicochemical property of fly ash on mechanical property and mineralogical aspects of hardened materials. There are suitable range of $\mathrm{Si} / \mathrm{Al}$ ratio of glassy phase and preferable grain fineness of fly ash to obtain enough strength and production amount of zeolite under constant mixing ratio of fly ash and sodium hydroxide. Gmelinite was the main products in any cases. On the hand, production amount of Zeolite NaP1, Hydroxysodalite and unidentified product with 9-10 broad peak in XRD depended upon the properties of fly ash. Strength showed good correlation with pore size distributing property of hardened materials. The low strength specimen had much porosity at diameter of $1-10 \mu \mathrm{m}$. On the other hand, high strength specimen showed less porosity in $1-10 \mu \mathrm{m}$ and much porosity in $0.01-0.1 \mu \mathrm{m}$. Cation exchange capacities of powderized hardened materials were $80-150$ $\mathrm{cmol} / \mathrm{kg}$, the higher reaction rate of fly ash, the higher cation exchange capacity. The partition coefficients for cecium were $33-71 \mathrm{~L} / \mathrm{g}$.

\section{Key words:}

Fly ash, Sodium hydroxide, Zeolite, Alkali activation, Hydrothermal reaction, Cation exchange ability, Cesium

\section{1 緒言}

石炭火力発電施設から発生する石炭灰は, 日本国内で 年間約 1000 万 $\mathrm{t}$ に達している。石炭灰の有効利用量拡大 が課題となっており, 特に, セメント・コンクリート用 の混和材として利用できない, 粗いフライアッシュに対 して新たな有効利用用途の開拓が求められている。近年, セメントに代わる構造材料として，アルミナ-シリカ質の 非晶質材料に水ガラスおよび水酸化アルカリを混練し， 蒸気養生により固化体を作製する技術，ジオポリマーが 注目され，フライアッシュの有効利用用途としても期待 されている2),3)。

筆者らは，水ガラスを用いずに水酸化アルカリとフラ イアッシュを混練し，水熱合成を施すことでゼオライト
を多量に含有する硬化体を作製し4), これは優れた強度と 陽イオン交換能, 特にセシウムに対し良好な吸着性能を 有することを報告している5)。また，使用する水酸化ナ卜 リウム濃度とフライアッシュの質量比が硬化体の強度お よび生成物，陽イオン交換能に影響を及ぼすため，利用 目的に沿った配合設計が必要であるとしている ${ }^{6}$ 。

一方で，フライアッシュを含めた石炭灰は発電所の施 設および炭種によって品質が異なり, 物理学的特性の変 更幅が比較的大きくなる。このように品質変動幅が大き いフライアッシュを原料とした場合，粉末状の人工ゼオ ライトを製造する仮定での反応機構と生成物量に影響を 及ぼすことが報告されている7)-9)。ゼオライト高含有硬化 体の諸性状も同様に変化する可能性があるため，化学的

本報を「水熱合成によるフライアッシュを主原料としたゼオライト高含有硬化体(第3報)」(Zeolite composed hardened material using fly ash cured under hydrothermal condition. III) とする. また, 第1報は材料64巻8号634頁 $(2015)$ に、第2 報は材料64巻8号641頁 (2015) に掲載済である.

$\dagger \quad$ 原稿受理 平成26年6月25日 Received June 25, 2014 @2015 The Society of Materials Science, Japan

* 正 会員 電力中央研究所 地球工学研究所 $\bar{\top} 270$-1194 我孫子市我孫子

Civil Engineering Research Laboratory, Central Research Institute of Electric Power Industry, Abiko, Abiko 270-1194.

** 電力中央研究所 地球工学研究所 $\bar{\top} 270-1194$ 我孫子市我孫子

Civil Engineering Research Laboratory, Central Research Institute of Electric Power Industry, Abiko, Abiko 270-1194.

*** 電力中央研究所 環境化学工学研究所 $\bar{\top} 270-1194$ 我孫子市我孫子

Environmental Science Research Laboratory, Central Research Institute of Electric Power Industry, Abiko, Abiko 270-1194

****電力中央研究所 エネルギー技術研究所 テ240-0196 横須賀市長坂

Energy Engineering Research Laboratory, Central Research Institute of Electric Power Industry, Nagasaka, Yokosuka, 240-0196 
Table 1 Chemical compositions of fly ash (mass\%).

\begin{tabular}{ccccccccccc}
\hline No. & $\mathrm{SiO}_{2}$ & $\mathrm{Al}_{2} \mathrm{O}_{3}$ & $\mathrm{Fe}_{2} \mathrm{O}_{3}$ & $\mathrm{TiO}_{2}$ & $\mathrm{MgO}$ & $\mathrm{CaO}$ & $\mathrm{Na}_{2} \mathrm{O}$ & $\mathrm{K}_{2} \mathrm{O}$ & $\mathrm{SO}_{3}$ & Ig.loss \\
\hline $\mathrm{A}$ & 62.9 & 20.0 & 4.5 & 1.3 & 1.1 & 1.7 & 0.1 & 1.3 & 0.7 & 2.0 \\
\hline $\mathrm{B}$ & 58.0 & 24.2 & 7.7 & 1.2 & 1.3 & 2.6 & 0.7 & 1.8 & 0.6 & 1.5 \\
\hline $\mathrm{C}$ & 60.7 & 24.4 & 4.6 & 1.6 & 2.0 & 3.5 & 0.01 & 0.6 & 0.5 & 1.9 \\
\hline $\mathrm{D}$ & 67.1 & 22.0 & 3.0 & 1.3 & 0.5 & 1.7 & 0.02 & 0.9 & 0.3 & 3.0 \\
\hline $\mathrm{E}$ & 62.1 & 20.2 & 7.3 & 1.2 & 1.8 & 2.5 & $<0.01$ & 1.4 & 0.5 & 2.5 \\
\hline $\mathrm{F}$ & 54.1 & 31.7 & 2.8 & 1.9 & 1.3 & 3.4 & 0.9 & 0.5 & 0.2 & 5.0 \\
\hline $\mathrm{G}$ & 59.1 & 21.0 & 6.3 & 1.3 & 0.6 & 1.8 & 0.5 & 1.1 & 0.2 & 7.6 \\
\hline $\mathrm{H}$ & 54.8 & 25.3 & 7.4 & 1.6 & 1.4 & 3.9 & 0.9 & 1.3 & 0.8 & 2.2 \\
\hline $\mathrm{I}$ & 55.9 & 25.8 & 5.4 & 1.6 & 0.9 & 2.0 & 0.6 & 1.2 & 0.3 & 6.1 \\
\hdashline $\mathrm{J}$ & 53.9 & 28.0 & 4.7 & 1.7 & 1.0 & 1.9 & 0.6 & 1.1 & 0.3 & 6.7 \\
\hline $\mathrm{K}$ & 61.2 & 22.3 & 6.4 & 1.3 & 1.2 & 2.4 & 0.6 & 1.3 & 0.4 & 2.7 \\
\hdashline $\mathrm{L}$ & 64.6 & 20.9 & 6.0 & 1.1 & 0.9 & 1.5 & 0.6 & 1.3 & 0.3 & 2.5 \\
\hline
\end{tabular}

Table 2 Mineralogical contents and $\mathrm{Si} / \mathrm{Al}$ ratio in glassy phase of fly ash.

\begin{tabular}{cccccc}
\hline No. & $\begin{array}{c}\text { Mullite } \\
\text { (mass\%) }\end{array}$ & $\begin{array}{c}\text { a-Quartz } \\
(\text { mass } \%)\end{array}$ & $\begin{array}{c}\text { Magnetite } \\
(\text { mass } \%)\end{array}$ & $\begin{array}{c}\text { glass } \\
\text { (mass\%) }\end{array}$ & $\begin{array}{c}\text { Si/Al(mol) } \\
\text { in glass }\end{array}$ \\
\hline A & 7.1 & 8.5 & 3.6 & 78.8 & 3.0 \\
\hline B & 11.1 & 17.9 & 1.4 & 68.1 & 1.9 \\
\hline C & 14.6 & 14.4 & 0.7 & 68.5 & 2.6 \\
\hline D & 12.0 & 17.1 & 0.9 & 67.0 & 3.0 \\
\hline E & 11.2 & 21.6 & 4.5 & 60.2 & 2.6 \\
\hline F & 20.3 & 9.7 & 0.1 & 70.0 & 1.9 \\
\hline G & 14.6 & 18.1 & 3.5 & 63.7 & 3.0 \\
\hline H & 13.8 & 11.0 & 1.8 & 73.4 & 2.2 \\
\hline I & 18.3 & 14.8 & 1.2 & 65.7 & 2.4 \\
\hline J & 20.8 & 12.1 & 0.3 & 66.7 & 2.3 \\
\hline K & 12.8 & 14.7 & 2.8 & 69.6 & 2.8 \\
\hline L & 11.3 & 15.2 & 2.4 & 71.1 & 3.1 \\
\hline
\end{tabular}

Table 3 Physical properties of fly ash.

\begin{tabular}{cccc}
\hline No. & $\begin{array}{c}\text { Density } \\
\left(\mathrm{g} / \mathrm{cm}^{3}\right)\end{array}$ & $\begin{array}{c}\text { Specific } \\
\text { area }\left(\mathrm{cm}^{2} / \mathrm{g}\right)\end{array}$ & $\begin{array}{c}\text { Median } \\
\text { size }(\mu \mathrm{m})\end{array}$ \\
\hline A & 2.31 & 3610 & 9.9 \\
\hline B & 2.28 & 2930 & 15.9 \\
\hline C & 2.10 & 3280 & 28.4 \\
\hline D & 2.18 & 2830 & 27.5 \\
\hline E & 2.31 & 3170 & 16.7 \\
\hline F & 2.16 & 3930 & 21.3 \\
\hline G & 2.12 & 2522 & 18.2 \\
\hline H & 2.18 & 2612 & 13.2 \\
\hline I & 2.14 & 2976 & 18.6 \\
\hline J & 2.22 & 3192 & 17.9 \\
\hline K & 2.19 & 2633 & 17.1 \\
\hline L & 2.16 & 2890 & 17.4 \\
\hline
\end{tabular}

性質および物理的性質の異なる複数の FA を対象にした 検討を行い，ゼオライト高含有硬化体に適した石炭灰を 選定する手法が必要である。

そこで, 本研究では JIS 規格外の複数の原粉フライアッ シュを用いて作製したゼオライト硬化体の強度特性およ びセシウムの吸着特性と陽イオン交換容量について検討 を行った。

$$
2 \text { 実 験 方 法 }
$$

\section{$2 \cdot 1$ 使用材料}

国内複数個所の火力発電所で発生した原粉フライアッ シュ（以下FA）を使用し，それぞれの化学組成を Table 1 に，鉱物組成およびガラス化率，ガラス質の $\mathrm{Si} / \mathrm{Al}$ (mol 比）を Table 2 に, 物理的性質を Table 3 に示した。石炭の 燃焼温度はおよそ $1400 \sim 1500^{\circ} \mathrm{C}$ で，原粉フライアッシュ はボイラー下流の電気集塵機で集められた飛灰（フライ アッシュ）を集積，貯蔵する原粉サイロから採取した。 化学組成は波長分散型 XRF（島津製作所製 XRF-1500）に
より分析し，鉱物相は内部標準法によって定量した。ガ ラス化率とガラス相の $\mathrm{Si} / \mathrm{Al}$ は，鉱物相以外をガラス相と して計算により求めた。水酸化アルカリ溶液は水酸化ナ トリウム特級試薬をイオン交換水に溶解させ, 室温まで 冷却して作製した。

\section{$2 \cdot 2$ 硬化体の作製}

$\mathrm{FA}$ と水酸化ナトリウム, 水は $\mathrm{NaOH} / \mathrm{FA}=4.1 \sim 12.6 \mathrm{mass} \%$, water/FA=33.8mass\%の割合で混合し，ミキサー（HOBART 製ミキサ N-50）で 5 分間練混ぜ，ペーストを作製した。 ペーストは $40 \mathrm{~mm} \times 40 \mathrm{~mm} \times 160 \mathrm{~mm}$ の型枠に流し込み成 形し, テーブルバイブレータで 4 分間の振動を与えた。 $80^{\circ} \mathrm{C}$ 湿潤環境で 24 時間養生し,オートクレーブにて $180^{\circ} \mathrm{C}$ (1.0MPa) で 6 時間水熱合成を行った。なお, 脱型は $80^{\circ} \mathrm{C}$ 湿潤養生開始から 1 時間後に脱型可能な強度を有してい ることを確認して行った。また, 硬化体中に吸着した水 分量を統一寸るため, 作成後に $60^{\circ} \mathrm{C}$ 乾燥を 7 日間施した。

\section{$2 \cdot 3$ 微細組織の分析}




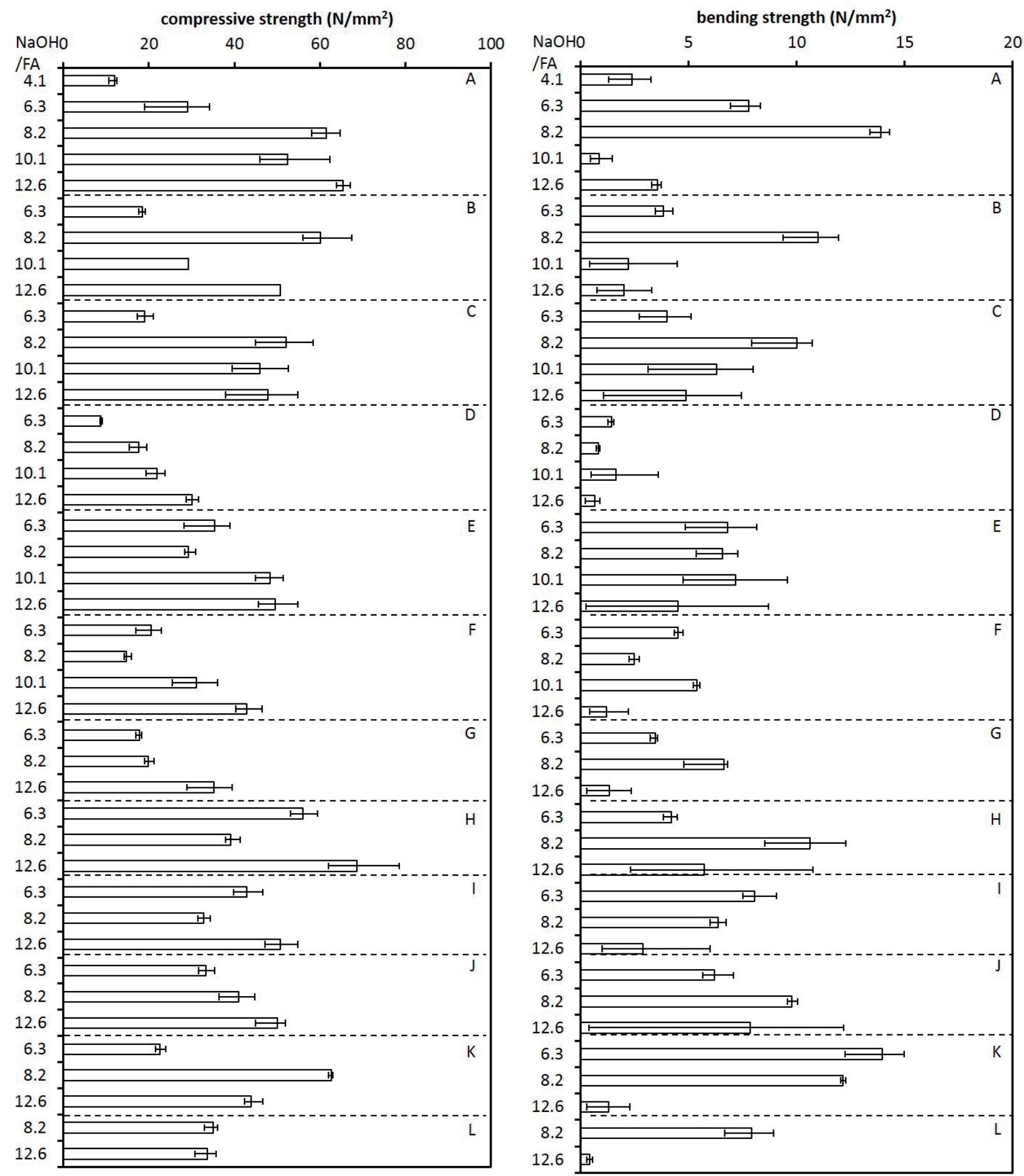

Fig. 1 Strength of hardened samples.

圧縮強度，曲げ強度は強度試験機（島津製作所製 UH-1000kNI）を用い，JIS R5201 に準じて測定した。生成 物は XRD（リガク製 RINT2000）により同定し，細孔径 分布は水銀ポロシメータ (Micromeritics 製 auto poreIV 9510）により測定した。なお，水銀ポロシメータ用の試 料は, 硬化体を $5 \mathrm{~mm}$ 角に切り出し, アセトンに 24 時間 浸漬させ， $20^{\circ} \mathrm{C}$ 風乾を 1 時間，D-dry を 24 時間施して作 製した。
FA の反応率 $(\alpha)$ は選択溶解法により測定した。まず, 粉砕した試料を $4 \mathrm{~N}$ 塩酸溶液に浸漬させ, $60^{\circ} \mathrm{C}$ 環境に湯浴 させながら 15 分間の往復振とうを行った。遠心分離 （3000rpm）により固液分離した後に上澄夕液を除去し, およそ $80^{\circ} \mathrm{C}$ の湯による洗浄と遠心分離，上澄夕液の除去 を 3 回繰り返した。次に, 先ほどの処理の不溶残分を $5 \mathrm{mass} \% \mathrm{Na}_{2} \mathrm{CO}_{3}$ 溶液に浸漬させ， $80^{\circ} \mathrm{C}$ 環境に湯浴させな がら 20 分間の往復振とうを行った。遠心分離 (3500rpm) により固液分離した後に上澄夕液を除去し，およそ $80^{\circ} \mathrm{C}$ 


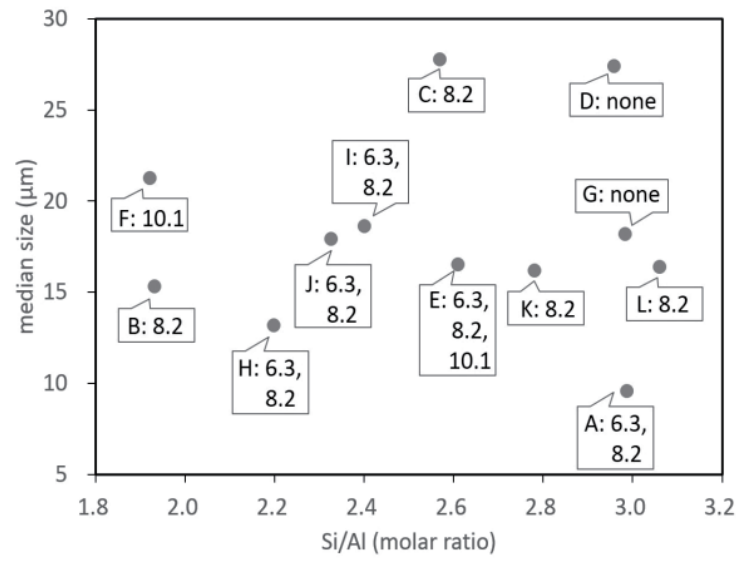

Fig. 2 Relation among physicochemical properties of fly ash, $\mathrm{Si} / \mathrm{Al}$ ratio and median particle size and $\mathrm{NaOH} / \mathrm{FA}$ value that mortars showed higher strength than ordinary concrete (compressive strength $=30 \mathrm{~N} / \mathrm{mm}^{2}$, bending strength $=5 \mathrm{~N} / \mathrm{mm}^{2}$ )

の湯による洗浄と遠心分離, 上澄み液の除去を再び 3 回 繰り返した。粉体の初期重量に対し，各操作の固液比は $1 \mathrm{~g}: 30 \mathrm{ml}$ とした。選択溶解処理後のサンプルの固形残分量 $\left(R_{S}\right)$ と原料 FA の固形残分量 $\left(R_{F A}\right)$ を測定した。 $110^{\circ} \mathrm{C}$ から $950^{\circ} \mathrm{C}$ にかけての強熱減量 $(I)$ と，XRF によるサン プル中 $\mathrm{Na}$ 含有率 $\left(M_{N a}\right)$ の定量を行い, 反応率を以下の 式(1)により算出した。

$$
\alpha=1-\frac{R_{S}}{\left(1-I-M_{N a}\right) \cdot R_{F A}}
$$

\section{$2 \cdot 5$ 陽イオン交換能の測定}

セシウムの分配係数の測定は「福島第一原子力発電所 事故によって放出された放射性物質の除去・回収技術の ためのデータベース」10)を参考に行った。粉砕した硬化体 のうち， $0.425 \mathrm{~mm}$ 篩通過分を脱イオン水で水洗し, $40^{\circ} \mathrm{C}$ 乾燥を 24 時間施して供試体とした。塩化セシウムを用い, カドミウムのイオン溶液を $1.0 \mathrm{mg} / \mathrm{L}$ かつ $\mathrm{pH} 5 \sim 6$ に調整し た。なお， $\mathrm{pH}$ の調整には $\mathrm{NaOH}$ および $\mathrm{HCl}$ を使用した。 粉砕試料 $1 \mathrm{~g}$ をセシウムイオン溶液 $100 \mathrm{ml}$ に浸漬, $120 \mathrm{rpm}$ の往復振とうを 24 時間行い，振とう後に 24 時間静置し た。上澄液を $0.45 \mu \mathrm{m}$ メンブレンフィルターでろ過し， セシウムの吸着量は，ろ液 $10 \mathrm{ml}$ に対し conc. $\mathrm{HNO}_{3}$ を $2 \mathrm{ml}$ 添加して検液として，ICP-MS（Agilent Technologies 製 Agilent $7500 \mathrm{Ce}$ ) を用いて定量し, 吸着量から分配係数を 1 点法により算出した。なお, 前報 ${ }^{5}$ においてゼオライト 高含有硬化体は $3.0 \mathrm{mgCs} / \mathrm{L}$ 以下の溶液に対する吸着等温 線がヘンリー型のとなることを報告している。陽イオン 交換容量（CEC）は和田・原田の方法 ${ }^{11 ）}$ に準拠し，JIS K 1478 の振とう・カリウム法（pH10）を用いて測定した。

\section{3 結 果 と 考 察}

\section{$3 \cdot 1$ 強度}

作製した硬化体の圧縮強度と曲げ強度を Fig. 1 に示す。 第 2 報において配合比は $\mathrm{NaOH} / \mathrm{FA}=8.2 \mathrm{mass} \%$, water/FA=33.8mass\%が最適であり, 最も高強度の硬化体が 得られたことを報告とした（灰 C が相当）。同配合はほと

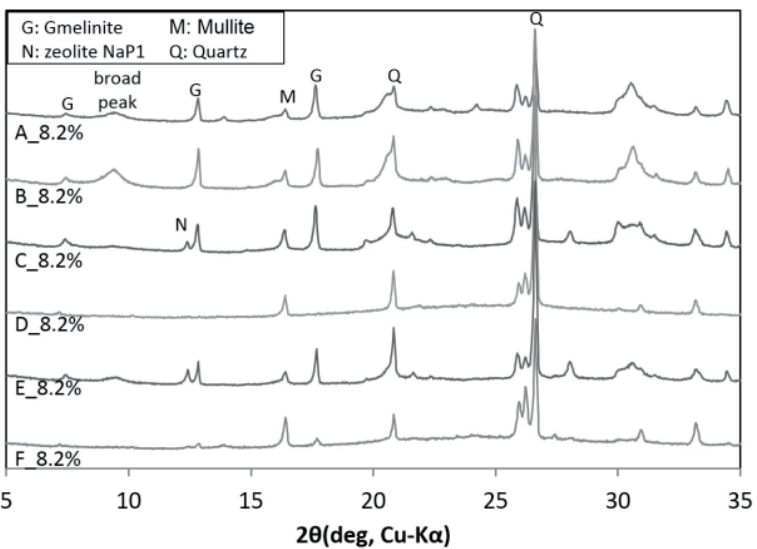

Fig. $3 \mathrm{XRD}$ profiles in case of $\mathrm{NaOH} / \mathrm{FA}=8.2 \mathrm{mass} \%$.

Table 4 Products in case of $\mathrm{NaOH} / \mathrm{FA}=8.2 \mathrm{mass} \%$.

\begin{tabular}{|c|c|}
\hline No. & Products \\
\hline A & $\begin{array}{l}\text { (OGmelinite, } \triangle \text { Hydroxysodalite, } \\
\text { Ounknown (peak at } 9-10^{\circ} \text { ) }\end{array}$ \\
\hline B & () Gmelinite, (Ounknown (peak at $9-10^{\circ}$ ) \\
\hline $\mathrm{C}$ & $\begin{array}{l}\text { () Gmelinite, (OZeolite NaP1, } \\
\Delta \text { unknown (peak at } 9-10^{\circ} \text { ) }\end{array}$ \\
\hline $\mathrm{D}$ & $\triangle$ Zeolite NaP1 \\
\hline$E$ & 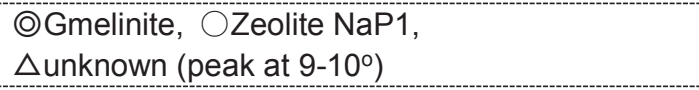 \\
\hline $\mathrm{F}$ & $\triangle$ Gmelinite, $\triangle$ Zeolite NaP1, $\triangle$ Hydroxysodalite \\
\hline G & $\triangle$ Gmelinite, $\triangle$ Zeolite NaP1 \\
\hline $\mathrm{H}$ & $\begin{array}{l}\text { (Gmelinite, } \triangle \text { Zeolite NaP1, } \triangle \text { Hydroxysodalite, } \\
\Delta \text { unknown (peak at } 9-10^{\circ} \text { ) }\end{array}$ \\
\hline I & 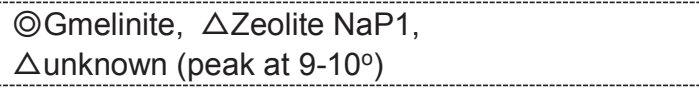 \\
\hline $\mathrm{J}$ & $\begin{array}{l}\text { (Gmelinite, OZeolite NaP1, } \\
\text { Ounknown (peak at 9-10) }\end{array}$ \\
\hline $\mathrm{K}$ & () Gmelinite, (Ounknown (peak at $9-10^{\circ}$ ) \\
\hline $\mathrm{L}$ & OGmelinite, $\triangle$ unknown (peak at $9-10^{\circ}$ ) \\
\hline
\end{tabular}

んどの灰を使用した場合でも，普通コンクリート（圧縮 強度 $30 \mathrm{~N} / \mathrm{mm}^{2}$ ，曲げ強度 $5 \mathrm{~N} / \mathrm{mm}^{2}$ を想定）と同等かそれ 以上の值を示しており，汎用的に使用しやすい配合であ ると考えられる。ただし $\mathrm{E}, \mathrm{I}, \mathrm{F}$ 灰は $6.3 \mathrm{mass} \%$

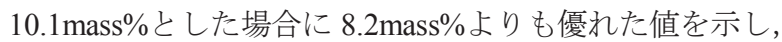

$\mathrm{D}, \mathrm{G}$ 灰はいずれの配合でも普通コンクリートよりも強度 が低かった。このことから, FA 毎に最適な $\mathrm{NaOH}$ 濃度が 異なることと, 原料に適していない灰があることを FAの 材料選定において考慮する必要があると考えられる。ま た, $\mathrm{NaOH} / \mathrm{FA}=12.6 \%$ と高濃度の場合にはすべての灰に共 通して圧縮強度は大きいが，曲げ強度は低い，もしくは 誤差範囲が大きく值が安定しておらず，前報と同様の傾 向がみられた。

Fig. 2 に, 各灰が普通コンクリートよりも優れた強度を 有する $\mathrm{NaOH} / \mathrm{FA}$ の值を, $\mathrm{Si} / \mathrm{Al}$ 比と Median 径に対し, 分 


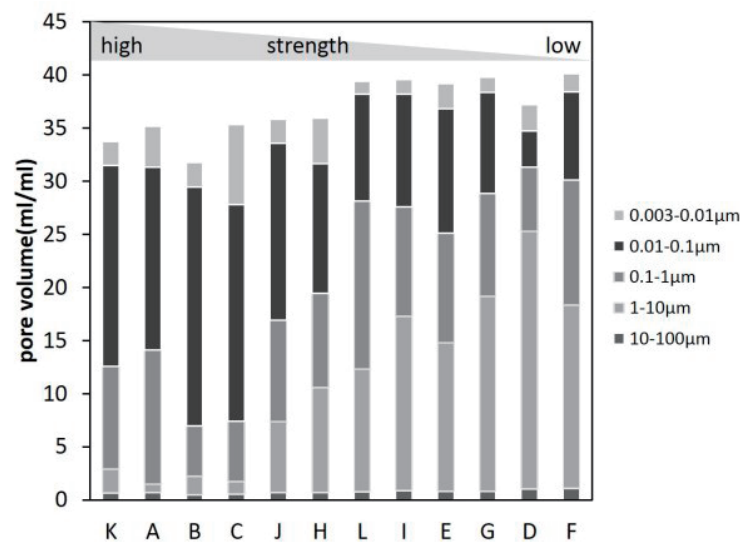

Fig. 4 Pore size distribution in case of $\mathrm{NaOH} / \mathrm{FA}=8.2 \mathrm{mass} \%$.

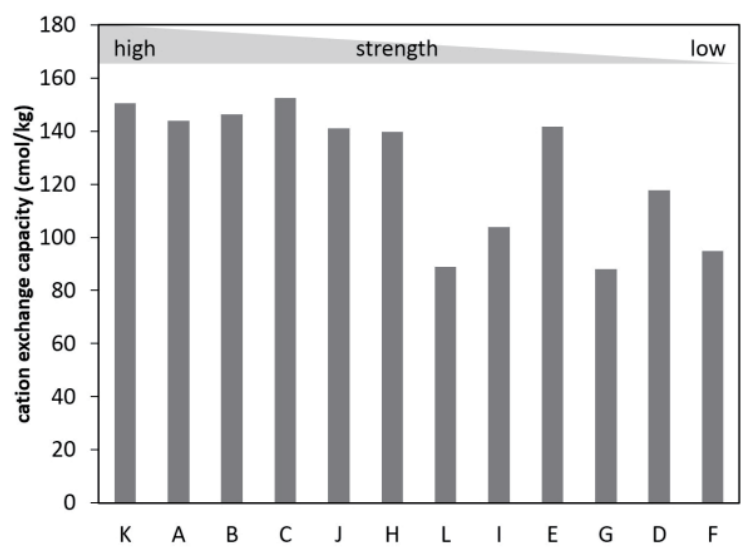

Fig. 6 Cation exchange capacity in case of $\mathrm{NaOH} / \mathrm{FA}=8.2 \mathrm{mass} \%$.

布中に記載した。なお，曲げ強度の最大值と最小值に倍 以上の差がある誤差範囲の大きい配合は除外した。

Median 径が 13 20 $\mu \mathrm{m}$ 程度の FA を比較した場合, $\mathrm{Si} / \mathrm{Al}$ が 2.2〜2.6の FA はより低い $\mathrm{NaOH} / \mathrm{FA}=6.3 \mathrm{mass} \%$ でも良好 な強度が得られた。これは生成物の $\mathrm{Si} / \mathrm{Al}$ 比とガラス質の 反応性によると考えられる。第一報において，EPMA の 結果より生成相の $\mathrm{Si} / \mathrm{Al}$ 比は約 3 となることを報告してい るが，FAのガラス質が約 2 と低い場合，Si 成分が不足し 易いためより多くのアルカリが必要になると推測される。 逆にガラス質の $\mathrm{Si} / \mathrm{Al}$ が大きい場合には, 中間酸化物であ る $\mathrm{Al}_{2} \mathrm{O}_{3}$ 成分が少ないことでアルカリによる影響を受け にくくなるため，反応性が低下していると考えられる。 また，A 灰も $6.3 \mathrm{mass} \%$ で良好な強度が得られた。これは FA 粒子が細かくいため反応性が向上していると考えられ る。逆に粗い灰では反応性が低下し，F 灰では最適な $\mathrm{NaOH} / \mathrm{FA}$ が 10.1 mass\%となり，D，G 灰では $\mathrm{Al}_{2} \mathrm{O}_{3}$ が少な いことも重なることで, アルカリ濃度を調整しても高強 度の硬化体が得られなかったと考えられる。

\section{$3 \cdot 2$ 生成物と微細組織}

$\mathrm{NaOH} / \mathrm{FA}=8.2 \mathrm{mass} \%$,の場合における A F 灰を使用した 硬化体の XRD パターンを Fig. 3 に示した。また，他の灰 も含めた生成物を Table 4 にまとめた。生成量の多寡はあ

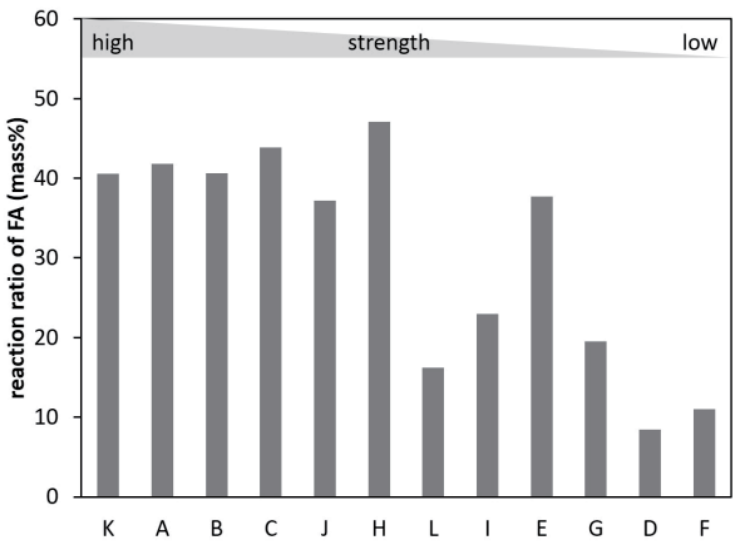

Fig. 5 Reaction ratio of fly ash in case of $\mathrm{NaOH} / \mathrm{FA}=8.2 \mathrm{mass} \%$.

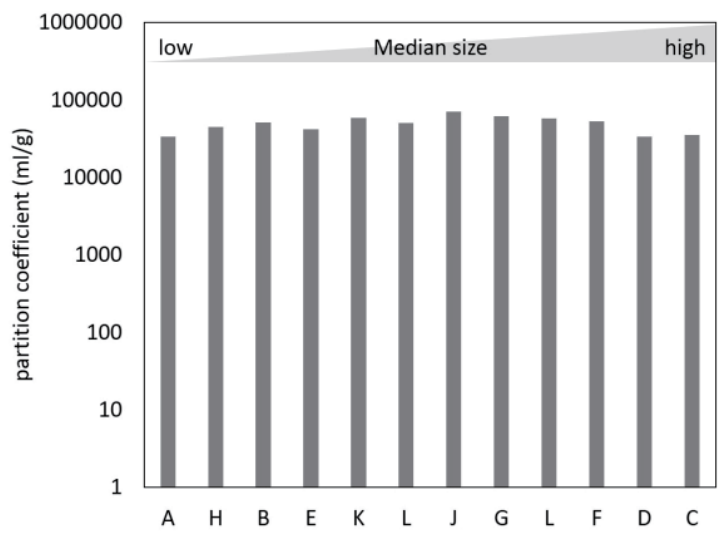

Fig. 7 Partition coefficient of cecium in case of $\mathrm{NaOH} / \mathrm{FA}=8.2 \mathrm{mass} \%$.

るが, ほとんどの灰に共通して主要生成物は Gmelinite (e.g. $\mathrm{Na}_{4} \mathrm{Al}_{4} \mathrm{Si}_{8} \mathrm{O}_{24} \cdot 12 \mathrm{H}_{2} \mathrm{O}$ ）であった。他の生成物は灰毎に異な り , Zeolite $\mathrm{NaP} 1$ ( e.g. $\mathrm{Na}_{6} \mathrm{Al}_{6} \mathrm{Si}_{10} \mathrm{O}_{32} \cdot 12 \mathrm{H}_{2} \mathrm{O}$ ), Hydroxysodalite (e.g. $\mathrm{Na}_{6} \mathrm{Al}_{6} \mathrm{Si}_{6} \mathrm{O}_{24} \cdot 7.5 \mathrm{H}_{2} \mathrm{O}$ ), 9〜10 のブ ロードピークの有無等が異なっていた。D灰のみ Gmelinite の生成が確認されなかった。Zeolite NaP1 はガラ ス質の $\mathrm{Si} / \mathrm{Al}$ がおおよそ 2.6 の灰を用いた場合に生成しや すい傾向にあった。Hydroxysodalite は Si/Al 比が大きく異 なる $\mathrm{A}$ 灰, $\mathrm{F}$ 灰で生成しており, これは $80^{\circ} \mathrm{C}$ 蒸気養生後 の主要生成物である Hydroxysodalite ${ }^{4}$ が水熱処理で反応せ ずに残存したものと考えられる。

細孔径分布を Fig. 4 に示した。なお, 高圧縮強度のサン プルを左から順に示した。強度の低減に伴い, 総細孔量 が微増するのに加え, 細孔径毎の頻度が異なっており, 低強度の硬化体は 1 10 $\mu \mathrm{m}$ の粗大な細孔が， 0.01-0.1 $\mu \mathrm{m}$ の微小な細孔が主体となっていた。そのため, ゼオライ 卜硬化体の強度は細孔量だけでなく, 細孔径分布にも大 きく影響を受けると考えられる。

FA の反応率を Fig. 5 に示した。細孔径分布と同様に高 強度の順に示した。 $\mathrm{H}$ 灰より高強度の硬化体は反応率が 40 50\%程の值であるのに対し，より低強度の硬化体は反 応率が低い傾向にあった。特に強度が $20 \mathrm{~N} / \mathrm{mm} 2$ 以下と低 
い G，D，F 灰は反応率が $20 \%$ 以下と低かった。一方で, $\mathrm{L}$ 灰は強度に対し反応率が著しく低く, E 灰は高い反応率 に関わらず強度が低い。40 N/mm2 以上の硬化体でも，反 応率が同程度でありながら強度に $10 \mathrm{~N} / \mathrm{mm} 2$ 以上の差があ る等, 強度と反応率には明らかな相関性は見られなかっ た。これらのうち，L 灰は $\mathrm{Si} / \mathrm{Al}$ 比が比較的大きいために 反応性が低下し, $\mathrm{E}$ 灰は $\mathrm{NaOH} / \mathrm{FA}=6.3 \mathrm{mass} \%$ を好適とする ことから $8.2 \mathrm{mass} \%$ の場合は過剰な濃度による強度低下と 推測される。灰毎の強度の差については, 不明な点が多 く, 特に蒸気養生後の主要生成物である Hydroxysodalite が残存した点や，最適な濃度の差異の影響について，今 後より詳細な検討が必要である。

\section{$3 \cdot 3$ 陽イオン交換能}

陽イオン交換容量を強度の順に Fig. 7 に示した。反応率 と高い相関性を有している傾向が見られ，D，F灰を含め た高反応性の灰ほど陽イオン交換容量が大きかった。こ れは反応率の増加により陽イオンの吸着サイトの形成数 が増加したためと考えられる。

セシウムに対する分配係数を Median 径の順に, Fig. 7 に示した。分配係数は 33〜 71L/g であり, 最も值が低い D 灰でも溶液のセシウムを $99.7 \%$ 以上吸着していた。灰毎の 違いが粒子径に対し僅かにみられ, Median 径が 10 20 $\mu \mathrm{m}$ の場合に大きく，粒子径が小さい A 灰と，大きい C, D 灰の值が小さかった。一方で， $\mathrm{Si} / \mathrm{Al}$ や反応率，生成物の 種類との相関性は全く見られず不明な点が多い。今後, 比表面積の変化やゲル生成物を含め, 詳細な検討が必要 である。

\section{4 結 言}

フライアッシュと水酸化ナトリウム水溶液を混練し, $180^{\circ} \mathrm{C}$ 水熱処理により作成するゼオライト高含有型硬 化体に対し, 発生施設の異なるフライアッシュを用い, 品質の違いが力学的特性や微細組織, セシウムに対する 陽イオン交換能等の諸性状について検討を行い，以下の ことが明らかとなった。

・フライアッシュ毎に適したアルカリ濃度が異なり，特 に $\mathrm{NaOH} / \mathrm{FA}=8.2 \mathrm{mass} \%(\mathrm{NaOH}$ 濃度 $5.89 \mathrm{~mol} / \mathrm{L})$ の場合に多 くの灰で普通コンクリートよりも優れた強度の硬化体が 得られた。但し，高 $\mathrm{Si} / \mathrm{Al}$ かつ粒度の粗い灰は適した配合 が得られなかった。

• $\mathrm{NaOH} / \mathrm{FA}=8.2 \mathrm{mass} \%(\mathrm{NaOH}$ 濃度 $5.89 \mathrm{~mol} / \mathrm{L})$ の場合に, 複 数の灰に通じて Gmelinite が主要生成物であり，Zeolite $\mathrm{NaP} 1$, Hydroxysodalite, $9 \sim 10^{\circ}$ のブロードピークの有無が フライアッシュ毎に異なっていた。

・硬化体の強度は細孔構造と相関性があり，低強度の硬 化体は 1 10 $\mu \mathrm{m}$ の粗大な細孔が中心であり, 強度が増加 するにつれて粗大な細孔が減少し，0.01-0.1 $\mu \mathrm{m}$ の微小な 細孔が中心となった。
・陽イオン交換容量は 80-150cmol $/ \mathrm{kg}$ で，フライアッシュ の反応率が大きい程，CEC も大きな值を示した。セシウ ムに対する分配係数は 33-71L/g であった。

本研究は経済産業省資源エネルギー庁の石炭利用技術 振興費書補助金「石炭灰の有効利用技術に関する研究」 の援助の下に実施しました。経済産業省資源エネルギー 庁の高倉寧氏，大森洋平氏，中山真氏に深く感謝いたし ます。

\section{参 考 文 献}

1) M. Hanai, "Nihon no sekitanbai riyou gijutsu joukyou to JCOAL no torikumi”, JCOAL journal, vol. 21, pp. 31-33 (2012).

2) A. Palomo, M.W. Grutzeck and M.T. Blanco, "Alkali-activated fly ashes A cement for the future", Cement and concrete Research, vol. 29, pp. 1323-1329 (1999).

3) C. Shi, A. F. Jimenez and A. Palomo, "New cements for the $21^{\text {st }}$ century: The pursuit of an alternative to Portland cement", Cement and concrete research, Vol. 41 pp. 750-763 (2011)

4) T. Yamamoto, "Development of manufacturing method for fly ash used high strength zeolite block", Civil engineering research laboratory report, No. N08068 (2009)

5) T. Sugiyama, T. Otsuka, S. Inoba, Y. Hiei and T. Yamamoto, "Zeolite composed hardened material using fly ash cured under hydrothermal condition (1); microstructure and cation exchange ability", Journal of the society of materials science, Japan, submitting

6) T. Sugiyama, T. Otsuka, S. Inoba, Y. Hiei and T. Yamamoto, "Zeolite composed hardened material using fly ash cured under hydrothermal condition (2); the influence of alkali dosage", Journal of the society of materials science, Japan, submitting

7) M. Meguro, J. Haruna, T. Noda and K. Tatuya, "Study on the chemical composition of coal fly ash as a raw material for artificial zeolite", Journal of the Japan society of waste Management Experts, vol. 8, No. 6, pp. 280-287 (1997).

8) K. Fukui, M. Kinugawa, T. Nshimoto and H. Yoshida, "Effect of fly ash content on zeolite synthesis from coal fly ash prepared by hydrothermal treatment”, Kagaku Kogaku Ronbun-shu, vol. 28, no. 2, pp. 155-160 (2002)

9) K. Fukui, H. Yoshida, H. Sakaguchi and M. Arita, "Zeolite synthesis from coal fly ash prepared by Hydro-thermal treatment method and effect of particle 
size on its reaction mechanism”, Kagaku Kogaku Ronbun-shu, vol 25, No. 6 pp. 987-992 (1999).

10) NIMS, "Database of promising adsorbents for decontamination of radioactive substances", http://reads.nims.go.jp./

11) K. Wada, "Cation-and anion-exchange capacity measurements for clays", Journal of the clay science society of Japan, vol. 21, pp. 160-163 (1981). 